\title{
PERAN WAKAF TERHADAP KESEJAHTERAAN MASYARAKAT
}

\author{
Diah Syifaul A’yuni \\ Institut Pesantren KH. Abdul Chalim Mojokerto \\ Email: diah.ayuni87@gmail.com
}

\begin{abstract}
Waqaf can be one solution to improve national development instruments. where endowments have a strategic role in improving the welfare of the people. Waqaf can help improve the quality of education, poverty alleviation, public health and help improve the economy of the community. In Indonesia, the practice of waqaf is still fairly unrealized. This is based on a lack of understanding of the meaning, purpose, form of endowments by the community. Especially in rural areas that basically their understanding is still mixed with classical understanding. Where if you want to carry out waqf, then you must have vacant land as an item to be represented. By cultivating waqaf like saving will make some people begin to be interested in doing it. At present there are many social activities that can improve the welfare of the community with waqaf.
\end{abstract}

Keywords: waqaf, welfare, community

\begin{abstract}
ABSTRAK
Wakaf bisa menjadi salah satu solusi untuk memperbaiki instrumen pembangunan nasional. dimana wakaf memiliki peran strategis dalam meningkatkan kesejahteraan umat. Wakaf bisa membantu meningkatkan mutu pendidikan, pengentas kemiskinan, kesehatan masyarakat dan membantu meningkatkan ekonomi masyarakat. Di Indonesia, praktek wakaf masih terbilang belum terealisasi dengan maksimal. Hal ini didasari oleh kurangnya pemahaman arti, tujuan, bentuk wakaf oleh masyarakat. Apalagi di daerah perdesaan yang pada dasarnya pemahaman mereka masih tercampur dengan pemahaman klasik. Dimana jika ingin melalukan wakaf, maka kita harus mempunyai tanah kosong sebagai suatu barang yang akan diwakafkan. Dengan membudayakan wakaf seperti menabung akan membuat beberapa masyarakat akan mulai tertarik untuk melakukannya. Saat ini banyak muncul kegiatan-kegiatan yang bersifat sosial yang bisa meningkatkan kesejahteraan masyarakat dengan adanya wakaf.
\end{abstract}

Kata kunci: waqaf, kesejahteraan, masyarakat

\section{PENDAHULUAN}

Wakaf merupakan salah satu bentuk ibadah dan pengorbanan dimana wakif memberikan sebagian hartanya kepada orang yang membutuhkan dan bermanfaat bagi orang lain. Misalnya seperti tanah yang diwakafkan, hal ini banyaknya bukti banyak masjid yang berdiri di tanah yang diwakafkan bagi orang lain, sehingga wakif mendapatkan amalan yang tak pernah terputus, seperti pada zaman khulafaur rasyidin, dimana Umar bin Khattab memperoleh sebidang tanah, kemudian Rasulullah menyarankan untuk mensedekahkan tanahnya beserta hasil manfaatnya diberikan ke fakir miskin. Praktek wakaf di Indonesia biasanya sering kali berupa tanah, rumah, 
masjid. Dan itu pun hanya orang-orang yang memiliki kelebihan uang, dan umumnya tanah memiliki nilai harga jual yang tinggi saat ini, dimana setiap orang membutuhkan tanah untuk didirikan sebuah rumah untuk dihuni. Sedangkan banyak warga Indonesia yang hidup di angka kemiskinan, yang demikian menimbulkan banyak pertanyaan bagaimana bisa mempraktekkan wakaf berupa sebidang tanah sedangkan untuk mereka hidup saja masih mengalami kekurangan, hanya bisa untuk makan sehari-hari dan menghidupi keluarga saja.

Dari uraian diatas, praktek wakaf di Indonesia masih terbilang belum terealisasi dengan maksimal. Hal ini didasari oleh kurangnya pemahaman arti, tujuan, bentuk wakaf oleh masyarakat. Apalagi di daerah perdesaan yang notaben pemahaman mereka masih tercampur dengan pemahaman klasik. Dimana jika ingin melalukan wakaf, maka kita harus mempunyai tanah kosong sebagai benda yang akan diwakafkan. Wakaf di Negara tetangga seperti Malaysia, oleh pemerintah Malaysia memperbolehkan perusahaan swasta yang bukan badan ataupun lembaga agama boleh ikut mengelolah perwakafan, pemerintah Malaysia berharap dapat meningkatkan tingkat pengembalian wakaf dan pengelolaan wakaf yang tinggi, serta semua kalangan dapat memperoleh manfaat yang diberikan dan diharapkan pihak swasta dapat mebuat efesiensi ekonomi dan meningkatkan wakaf yang lebih produktif. Dalam hal ini penulis ingin memberikan sebuah gagasan untuk sedikit menyelesaikan masalah wakaf di Indonesia.

\section{TERMINOLOGI WAKAF}

Sebagian besar penduduk Indonesia hidup dibawah garis kemiskinan, dan hidup dalam kondisi yang kurang layak. Pemerintah sudah melakukan upaya dalam hal memberikan bentuan dalam bentuk tunai maupun non tunai, namun dalm prakteknya itu sangat tidak efektif, apalagi di pedesaan seringnya terjadi perkembangan penduduk di desa. Menurut data yang dimiliki oleh Departemen Agama, pelaksanaan wakaf di Indonesia sampai sekarang masih didominasi pada penggunaan untuk tempat-tempat ibadah seperti masjid, pondok pesantren, mushola dan keperluan ibadah lainnya. Sedangkan penggunaan pemanfaatan untuk peningkatan kesejahteraan umum dalam bidang ekonomi masih sangat minim, bukan benda-benda produktif yang dapat mendatangkan kesejahteraan umat. Menyadari tentang kekurangan ini, Departemen 
Agama beserta Majelis Ulama, dan pihak terkait lainnya telah berupaya memperdayakan tanah-tanah tersebut dari pengelolaan tradisional konsumtif menjadi profesional produktif dengan cara penyuluhan hukum wakaf kepada masyarakat, menyusun RUU tentang wakaf yang sesuai dengan perkembangan masa kini dan mewujudkan Badan Wakaf Indonesia (BWI) sebagai lembaga yang mengelola wakaf secara nasional.

Praktek wakaf di indonesia sangat bermanfaat untuk meningkatkan kesejahteraan masyarakat dengan mengentaskan kondisi kemiskinan. Dari data yang ada, jumlah penduduk miskin nasional, persentase penduduk miskin didaerah perkotaan pada September 2015 tercatat 8,22\% juga turun menjadi 7,79\% pada maret 2016. Sementara pada September 2015 persentase penduduk miskin di daerah perdesaan naik dari 14,09 \% menjadi 14, 11\% pada Maret 2016. (Suryamin Republika.co.id). Wakaf bisa menjadi salah satu solusi untuk memperbaiki instrumen pembangunan nasional karena wakaf memiliki peran strategis dalam meningkatkan kesejahteraan masyarakat dengan membantu meningkatkan mutu pendidikan, pengentas kemiskinan, kesehatan masyarakat dan membantu meningkatkan ekonomi masyarakat.

Wakaf dapat mengetas kemiskinan dan pengangguran di Indonesia, jika di ambil garis kesimpulan bahwa dari benda yang sederhana dan bermanfaat apabila kita wakafkan bisa menjadi pecetus kegiatan selanjutnya. Dengan memulai dari hal yang kecil yang nantinya akan membawa kesadaran bagi masyarakat akan pentingnya wakaf. Wakaf mampu mengetas kemiskinan apabila prospek dan arah tujuannya tepat pada arah sasarannya. Tidak hanya itu saja, kesadaran dari masyarakat menjadi kunci penting dalam menumbuhkan kegiatan wakaf itu sendiri. Memberi pemahaman dan informasi yang tepat akan mudahnya wakaf di era globalisasi ini. Apalagi wakaf yang saat ini bisa berupa apa saja asal bermanfaat untuk dunia dan akhirat. Dengan membudayakan wakaf seperti menabung akan membuat beberapa masyarakat akan mulai tertarik untuk melakukannya. Saat ini banyak muncul kegiatan-kegiatan yang bersifat sosial terutama pada segi perekonomiannya.

Wakaf Menurut bahasa (etimologi) adalah tertahan. Secara istilah syari' (terminologi) adalah: Menahan suatu benda dan membebaskan / mengalirkan manfaatnya. Jadi maksudnya adalah menahan harta milik pribadi yang diserahkan kepada pihak lain untuk kepentingan umum dengan tujuan mendapatkan ridlo Allah 
SWT. Sedangkan menurut kamus besar bahasa Indonesia wakaf itu adalah benda bergerak atau tidak bererak yang disediakan untuk kepentingan umum (Islam) sebagai pemberian yang ikhlas.

Dasar hukum pelaksanaan wakaf;

Artinya : kamu sekali-kali tidak sampai kepada kebajikan (yang sempurna), sebelum kamu menafkahkan sehahagian harta yang kamu cintai. dan apa saja yang kamu nafkahkan Maka Sesungguhnya Allah mengetahuinya

Artinya : ... dan apa saja harta yang baik yang kamu nafkahkan (di jalan Allah), Maka pahalanya itu untuk kamu sendiri. dan janganlah kamu membelanjakan sesuatu melainkan karena mencari keridhaan Allah. dan apa saja harta yang baik yang kamu nafkahkan, niscaya kamu akan diberi pahalanya dengan cukup sedang kamu sedikitpun tidak akan dianiaya (dirugikan).

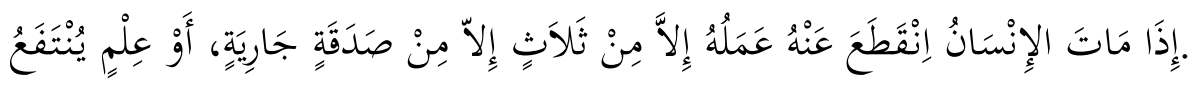

Artinya : Apabila seorang manusia meninggal dunia, terputus darinya amalnya kecuali dari tiga hal dari sedekah jariyah, ilmu yang bermanfaat, atau anak saleh yang mendoakannya." (HR. Muslim)

\section{RUKUN WAKAF}

Menurut jumhur ulama kebanyakan, mereka sepakat bahwa rukun wakaf ada empat, yaitu:

1. Al-waqif (orang yang mewakafkan), dengan syarat :

a. Berakal

b. Dewasa pemikirannya (rasyid).

c. Sudah berusia baligh dan bisa bertransaksi.

d. Orang yang merdeka (bukan budak).

2. Al-mauquf (harta yang diwakafkan)

Berdasarkan jenis benda yang diwakafkan, maka wakaf terbagi menjadi tiga macam:

a. Benda / barang yang berupa benda yang diam/tidak bergerak, seperti tanah, rumah, toko, dan yang semisalnya. 
b. Benda / barang yang bisa dipindah/bergerak, seperti mobil, hewan, dan semisalnya

c. Wakaf berupa uang.

Adapun syarat syarat nya adalah :

1) Harta tersebut telah diketahui dan jelas bendanya.

2) Benda tersebut adalah milik pribadi yang mewakafkan.

3) Harta yang diwakafkan adalah benda yang bermanfaat dan memiliki daya tahan lama.

3. Al - mauquf 'alaih (pihak yang dituju dari wakaf tersebut), dengan syarat

a. Berakal

b. Dewasa pemikirannya (rasyid).

c. Sudah berusia baligh dan bisa bertransaksi.

d. Orang yang merdeka (bukan budak belian).

Dipandang dari sisi pemanfaatannya, maka wakaf terbagi menjadi dua:

1) Wakaf yang sifatnya tertuju pada keluarga (individu)

2) Wakaf untuk amalan-amalan kebaikan. Wakaf ini diarahkan untuk kemaslahatan masyarakat di suatu negeri. Inilah jenis wakaf yang paling banyak dilakukan, seperti untuk masjid, madrasah,

4. Shighah (lafadz dari yang mewakafkan).

a. Adapun lafadz shighoh, para ulama membaginya menjadi dua bagian: Lafadz yang sharih, yaitu lafadz yang dengan jelas menunjukkan wakaf dan tidak mengandung makna lain.

b. Lafadz kinayah, yaitu lafadz yang mengandung makna wakaf meskipun tidak secara langsung dan memiliki makna lainnya, namun dengan tanda - tanda yang mengiringinya menjadi bermakna wakaf.

Untuk lafadz yang pertama, maka cukup dengan diucapkannya akan berlaku hukum wakaf. Adapun lafadz yang kedua ketika diucapkan akan berlaku hukum wakaf jika diiringi dengan niat wakaf atau lafadz lain yang dengan jelas menunjukkan makna wakaf. 
Wakaf memiliki banyak hikmah dan manfaat baik bagi yang mewakafkan atau untuk pengguna wakaf. Untuk itu di bawah ini akan disebutkan sebagian kecil dari hikmah dan manfaat wakaf:

1. Hikmah wakaf

a. Menghilangkan sifat tamak dan kikir manusia atas harta yang dimilikinya.

b. Menanamkan kesadaran bahwa di dalam setiap harta benda itu meski telah menjadi milik seseorang secara sah, tetapi masih ada di dalamnya harta agama yang mesti diserahkan sebagaimana halnya juga zakat.

c. Menyadarkan seseorang bahwa kehidupan di akhirat memerlukan persiapan yang cukup . Maka persiapan bekal itu diantaranya adalah harta yang pernah diwakafkan

d. Dapat menopang dan mengerakan kehidupan sosial kemasyarakatan umat islam, baik aspek ekonomi, pendidikan, sosial budaya dan lainnya.

2. Manfaat wakaf

Di antara manfaat wakaf baik bagi wakif dan pengguna wakaf adalah :

a. Pahala yang trus menerus mengalir selama benda yang diwakafkan masih dimanfaatkan walaupun si wakif sudah meninggal dunia.

b. Terus-menerusnya manfaat dalam berbagai jenis kebaikan dan tidak terputus dengan sebab berpindahnya kepemilikan.

\section{KESEJAHTERAAN MASYARAKAT}

Menurut Todaro dan Stephen C. Smith (2006), kesejahteraan masyarakat menunjukkan ukuran hasil pembangunan masyarakat dalam mencapai kehidupan yang lebih baik yang meliputi: pertama, peningkatan kemampuan dan pemerataan distribusi kebutuhan dasar seperti makanan, perumahan, kesehatan, dan perlindungan; kedua, peningkatan tingkat kehidupan, tingkat pendapatan, pendidikan yang lebih baik, dan peningkatan atensi terhadap budaya dan nilai-nilai kemanusiaan; dan ketiga, memperluas skala ekonomi dan ketersediaan pilihan sosial dari individu dan bangsa.

Kesejahteraan masyarakat adalah kondisi terpenuhinya kebutuhan dasar yang tercermin dari rumah yang layak, tercukupinya kebutuhan sandang dan pangan, biaya pendidikan dan kesehatan yang murah dan berkualitas atau kondisi dimana setiap 
individu mampu untuk memnuhi kebutuhan hidupnya sendiri dengan pendapatan yang mereka peroleh. Kesejahteraan bisa diartikan sebagai kondisi dimana kebutuhan masyarakat terpenuhi, kebutuhan ini tidak hanya kebutuhan pokok saja tapi juga kebutuhan yang lainnya. Dalam pengukuran kesejahteraan masyarakat digunakan pendapatan perkapita sebagai tolak ukurnya. Semakin tinggi pendapatan perkapita suatu negara maka kesejahteraan masyarakatnya semakin tinggi, begitupun sebaliknya. Selain aspek pendapatan perkapita, kesejahteraan masyarakat bisa dilihat dari kebutuhankebutuhan yang dipenuhi seperti kebutuhan pangan, sandang, tempat tinggal dan pendidikan

Saat ini kemiskinan dan pengangguran masih menjadi masalah yang belum terselesaikan. Walaupun pemerintah telah menerapkan berbagai kebijakan, namun kebijakan pemerintah itu belum mampu mengentaskan kemiskinan. Kemiskinan merupakan persoalan yang penting, yang dapat merajalela dan berpengaruh kepada sistem kehidupan yang lebih makro, sehingga tidak ada jalan lain kecuali harus dihilangkan. Kemiskinan yang terjadi dalam masyarakat sebenarnya bukan hanya menjadi tanggung jawab pemerintah, tetapi merupakan tanggungjawab bersama antara pemerintah dan masyarakat. Untuk menghadapi masalah kemiskinan tersebut, dalam Islam ada beberapa lembaga yang potensial untuk dikembangkan untuk mengatasi kemiskinan, salah satu di antaranya adalah wakaf.

Untuk menghadapi masalah kemiskinan tersebut, sebagaimana pengalaman Mesir dan Turki sudah seharusnya kita mengembangkan wakaf produktif. Sudah selayaknya bangsa Indonesia umumnya dan umat Islam khususnya menyambut baik kehadiran Undang-Undang Nomor 41 Tahun 2004 tentang Wakaf karena Benda yang diwakafkan yang diatur dalam undang-undang tentang wakaf ini tidak dibatasi benda tidak bergerak saja, melainkan juga benda-benda bergerak lainnya yang tidak bertentangan dengan syariat Islam termasuk wakaf uang dan surat berharga. Peran wakaf sangat penting terhadap kesejahteraan masyarakat untuk itu diperlukan pengelolaan wakaf yang baik agar tujuan ini bisa tercapai. Wakaf memiliki banyak tujuan diantara tujuan ibadah kepada Allah SWT dan juga tujuan sosial yakni membantu dalam proses pembangunan ekonomi masyarakat dengan mengentaskan kemiskinan dan meningkatkan kesejahteraan masyarakat. Untuk itu disarankan agar pengelolaan wakaf 
ini bisa dilakukan semaksimal mungkin mengingat pentingnya tujuan wakaf yang sangat berarti bagi manusia

Kesejahteraan masyarakat merupakan tujuan utama di dalam pembangunan. Pemerintah didalam setiap implementasi kebijakan selalu menjadikan kesejahteraan sebagai tujuan yang hendak dicapai. Salah satu kebijakan pusat yang diharapkan dapat memberikan kesempatan bagi masyarakat daerah puncak dalam mencapai kesejahteraan bersama adalah dengan otonomi daerah. Melalui desentralisasi, daerah diberikan keleluasaan untuk membangun dan memprakarsai pembangunan daerahnya sendiri, dan juga lebih mendekatkan kesejahteraan kepada masyarakat.

Pemberlakuan UU No 32 Tahun 2004 tentang Pemerintahan Daerah memberikan nafas baru bagi upaya membangun keterlibatan masyarakat di daerah dan juga meningkatkan potensi yang dimiliki daerah untuk kepentingan masyarakat. Peningkatan pelayanan, pemberdayaan dan peran serta masyarakat menjadi kata kunci pelaksanaan otonomi daerah. Karena semangat dari otonomi daerah adalah mendekatkan pelayanan pemerintah kepada warga negara yang selama masa pemerintahan orde baru lebih bercorak sentralistis (Jakarta minded). Lebih dari satu dasawarsa, sejak kebijakan desentralisasi diberlakukan, telah banyak hal yang terjadi didaerah. Pemerintah terlihat juga terus berupaya untuk selalu mengembangkan pola dan sistem pelaksanaan desentralisasi tersebut. Pendek kata, desentralisasi memberikan ruang bagi daerah untuk menyusun strategi pembangunan daerah yang lebih baik agar kesejahteraan masyarakat dapat dicapai.

Strategi pembangunan daerah tentu tidak bisa serampangan dilakukan. Perlu strategi yang terukur dan sistematis agar bisa mencapai tujuan dengan efektif dan efisien. Beberapa hal yang penting yang dapat dipedomani didalam implementasi strategi pembangunan daerah. Pertama, pemihakan kepada rakyat (pro rakyat). Strategi ini merupakan salah satu pendekatan paling tepat untuk percepatan pembangunan daerah. Sebab, strategi pemihakan berhubungan erat bagaimana pemerintah daerah turut membuka ruang keterlibatan atau partisipasi masyarakat seluas-luasnya. Pemihakan juga menjadi penting mengingat otonomi daerah memang ditujukan agar masyarakat dapat memperoleh kesejahteraan dalam kehidupannya. Pemihakan juga sangat krusial bagi pembangunan, terutama untuk daerah-daerah pesisir dan pulau-pulau kecil yang 
umumnya rentan terhadap perubahan kondisi lingkungan akibat berbagai aktivitas manusia.

Pemihakan juga sangat penting untuk memperkecil kesenjangan antara wilayah relatif cepat berkembang dengan pulau-pulau kecil di wilayah perbatasan. Pada tahapan ini, pemihakan akan diarahkan untuk memperbaiki dan memperkuat berbagai program pemerintah dalam membangun daerah. Kedua, melaksanakan pembenahan terhadap seluruh aspek penting daerah, seperti aset, sumber daya dan birokrasi. Pembenahan dinilai sebagai salah satu strategi yang akan mendukung program pembangunan di daerah. Apa saja yang perlu dibenahi? 1). Dalam koridor reformasi pemerintahan, pembenahan diarahkan pada reformasi institusional, mekanisme dan kinerja pelayanan dari berbagai institusi publik berdasarkan prinsip good governance dan clean government sehingga semua institusi ini dapat berperan optimal dalam meningkatkan kesejahteraan masyarakat. Regulasi-regulasi daerah yang dinilai tidak relevan dengan penyelenggaraan otonomi daerah harus disesuaikan.

Pembenahan juga menjadi strategi didalam membangun struktur pemerintahan dan wilayah, terutama untuk wilayah yang baru dimekarkan. Dalam kerangka struktur pemerintahan, pemerintah harus menerapkan prinsip pemerintahan berbasis kinerja dan rekruitmen PNS serta promosi pejabat berdasarkan kompetensi dan track record. Dalam koridor reformasi ekonomi, pembenahan dilakukan untuk menyokong kepentingan yang menjadi basis ekonomi masyarakat. Pemerintah daerah harus menyediakan infrastruktur dasar ekonomi, seperti pasar dan sistem. Selain itu, pembenahan atas perjanjianperjanjian perdagangan dan kerjasana seperti Border Crossing Agreement perlu untuk dilakukan.

Selain itu, pembenahan juga ditujukan untuk memangkas kebijakan-kebijakan dan regulasi penyebab biaya ekonomi tinggi, rencana tata ruang wilayah ( $R T$ dan RW), penyiapan master plan di setiap bidang pembangunaan sektor-sektor ekonomi strategis. Pemerintah daerah juga harus menyiapkan lokasi-lokasi industrial estate, kemudahan pengurusan pertanahan, penciptaan insentif untuk investor serta penerbitan perda investasi daerah. Pembenahan juga diarahkan untuk bangaimana memanfaatkan dan mengelola sumberdaya sehingga membawa kemaslahatan kepada masyarakat daerah. 
Ketiga, melaksanakan percepat an pembangunan daerah, dengan merancang skala prioritas terhadap aspek-aspek pembangunan daerah. Percepatan juga diarahkan terutama didalam memicu investasi dan pengembangan kegiatan-kegiatan sektor riil dan sektor ekonomi unggulan. Adanya percepatan, terutama dalam bidang ekonomi akan mampu menciptakan lapangan kerja dan mengurangi penduduk miskin serta jumlah pengangguran. Keempat, memanfaatkan teknologi informasi dan komunikasi yang mampu memaksimalkan kemampuan daerah didalam pembangunan. Teknologi yang banyak dikelola saat ini adalah dalam bentuk e-commerce. Hal ini tentu ditujukan dalam rangka penguatan kelembagaan perbaikan kualitas produk andalan daerah.

Dari data yang diperoleh, jumlah penduduk miskin nasional, persentase penduduk miskin didaerah perkotaan pada September 2015 tercatat 8,22\% juga turun menjadi 7,79 \% pada maret 2016. Sementara pada September 2015 persentase penduduk miskin di daerah perdesaan naik dari 14,09\% menjadi 14, 11\% pada Maret 2016. (Suryamin Republika.co.id). Wakaf bisa menjadi salah satu solusi untuk memperbaiki instrumen pembangunan nasional karena wakaf memiliki peran strategis dalam meningkatkan kesejahteraan masyarakat dengan membantu meningkatkan mutu pendidikan, pengentas kemiskinan, kesehatan masyarakat dan membantu meningkatkan ekonomi masyarakat.

\section{KESIMPULAN}

Peran wakaf sangat penting terhadap kesejahteraan masyarakat untuk itu diperlukan pengelolaan wakaf yang baik agar tujuan ini bisa tercapai. Wakaf memiliki banyak tujuan diantara tujuan ibadah kepada Allah SWT dan juga tujuan sosial yakni membantu dalam proses pembangunan ekonomi masyarakat dengan mengentaskan kemiskinan dan meningkatkan kesejahteraan masyarakat. Untuk itu disarankan agar pengelolaan wakaf ini bisa dilakukan semaksimal mungkin mengingat pentingnya tujuan wakaf yang sangat berarti bagi manusia.

Dengan mengoptimalkan seluruh potensi wakaf, maka insya Allah kesejahteraan dan kemandirian umat dapat terwujud. Kemiskinan dan ketidaksejahteraan ini terjadi karena tidak adanya kesadaran seluruh pihak, bahwa manfaat wakaf yang dikelola secara modern dan profesional dapat membawa kesejahteraan dan kemandirian masyarakat. Oleh karena itu, Pemerintah dan badan yang berwenang berperan aktif dalam 
menggiatkan wakaf produktif dengan agenda dan program-program yang mudah diterima di tengah masyarakat. Untuk selanjutnya memaksimalkan wakaf yang ada di Indonesia serta dikelola oleh nadzir yang amanah, kompeten, dan profesional, maka diharapkan tidak hanya sebatas wakaf. Akan tetapi dapat memberikan banyak manfaat. Khususnya kepada masyarakat dhuafa'.

\section{DAFTAR PUSTAKA}

Ali, Daud. Sistem Ekonomi Islam: Zakat dan Wakaf Jakarta: UI Press, 1988

Faizin, Hamam, “Mengembangkan Wakaf Produktif di Indonesia”, Jurnal Dialog, No. 70, Tahun XXXIII, Nopember 2010, Jakarta: Balitbangdiklat

Direktorat Pemberdayaan Wakaf, Pedoman Pengelolaan Wakaf Tunai, Kemenag RI, 2007.

Kabisi, Muhammad Abid Abdullah, Hukum Wakaf. Jakarta: Dompet Dhuafa Republika dan lman, 2004

Todaro, Michael P dan Stephen C Smith, “Pembangunan Ekonomi”Salemba Empat: 2013

Suhadi Imam, Wakaf Untuk Kesejahteraan Umat, Yogyakarta: Dana Bakti Prima Yasa 2002

Tim Depag, Paradigma Baru Wakaf di Indonesia (Jakarta: Direktorat Pengembangan Zakat dan Wakaf Ditjen bimbingan masyarakat Islam dan penyelenggaraan haji, 2004 bagian ketiga dan keempat).

Praja, Juhaya S. Perwakafan Di Indonesia, Bandung: Yayasan Piara, 1995

Panduan Pemberdayaan Tanah Wakaf Produktif Strategis di Indonesia, terbitan: Direktorat Pemberdayaan Wakaf Dirjen Bimas Islam, Depag RI, tahun 2008 